\title{
Human Milk Lactose, Insulin, and Glucose Relative to Infant Body Composition during Exclusive Breastfeeding
}

\author{
Ali S. Cheema ${ }^{1}{ }^{\mathbb{D}}$, Lisa F. Stinson ${ }^{1}$, Alethea Rea ${ }^{2}$, Ching Tat Lai ${ }^{1}{ }^{\mathbb{C}}$, Matthew S. Payne ${ }^{3,4}$, Kevin Murray $^{5}$, \\ Donna T. Geddes ${ }^{1}$ and Zoya Gridneva ${ }^{1, *(D)}$ \\ 1 School of Molecular Sciences, The University of Western Australia, Crawley, WA 6009, Australia; \\ alisadiq.cheema@research.uwa.edu.au (A.S.C.); lisa.stinson@uwa.edu.au (L.F.S.); \\ ching-tat.lai@uwa.edu.au (C.T.L.); donna.geddes@uwa.edu.au (D.T.G.) \\ 2 Mathematics and Statistics, Murdoch University, Murdoch, WA 6150, Australia; alethea.rea@murdoch.edu.au \\ 3 Division of Obstetrics and Gynaecology, UWA Medical School, The University of Western Australia, Crawley, \\ WA 6009, Australia; matthew.payne@uwa.edu.au \\ 4 Women and Infants Research Foundation, Subiaco, WA 6008, Australia \\ 5 School of Population and Global Health, The University of Western Australia, Crawley, WA 6009, Australia; \\ kevin.murray@uwa.edu.au \\ * Correspondence: zoya.gridneva@uwa.edu.au; Tel.: +61-8-6488-4467
}

Citation: Cheema, A.S.; Stinson, L.F.; Rea, A.; Lai, C.T.; Payne, M.S.; Murray, K.; Geddes, D.T.; Gridneva,

Z. Human Milk Lactose, Insulin, and Glucose Relative to Infant Body Composition during Exclusive Breastfeeding. Nutrients 2021, 13, 3724. https://doi.org/10.3390/ nu13113724

Academic Editor: Ekhard E. Ziegler

Received: 14 September 2021

Accepted: 21 October 2021

Published: 22 October 2021

Publisher's Note: MDPI stays neutral with regard to jurisdictional claims in published maps and institutional affiliations.

Copyright: (c) 2021 by the authors. Licensee MDPI, Basel, Switzerland. This article is an open access article distributed under the terms and conditions of the Creative Commons Attribution (CC BY) license (https:/ / creativecommons.org/licenses/by/ $4.0 /)$.
Abstract: Human milk (HM) components may influence infant growth and development. This study aimed to investigate relationships between infant body composition (BC) and HM lactose, insulin, and glucose (concentrations and calculated daily intakes (CDI)) as well as 24-h milk intake and maternal $\mathrm{BC}$ at 3 months postpartum. HM samples were collected at 2 months postpartum. Infant and maternal BC was assessed with bioimpedance spectroscopy. Statistical analysis used linear regression accounting for infant birth weight. 24-h milk intake and CDI of lactose were positively associated with infant anthropometry, lean body mass and adiposity. Higher maternal BC measures were associated with lower infant anthropometry, z-scores, lean body mass, and adiposity. Maternal characteristics including BC and age were associated with concentrations and CDI of HM components, and 24-h milk intake. In conclusion, 24-h intake of HM and lactose as well as maternal adiposity are related to development of infant BC.

Keywords: lactose; glucose; insulin; human milk; breastfeeding; infant; body composition; bioelectrical impedance spectroscopy; intake; lactation

\section{Introduction}

Human milk (HM) is typically the sole food source for the infants in the first 6 months of life, through which they acquire all elements necessary for their growth and development [1,2]. HM provides a constant supply of micro- and macronutrients, bioactive molecules including carbohydrates (lactose and glucose) and hormones (insulin) to the infant during early life, ensuring appropriate nutrition, maturation, and protection against infection and growth [3-5]. These components may also affect infant gut microbiota, appetite regulation and metabolism, as well as infant body composition (BC). Development of infant $\mathrm{BC}$ in the early months postpartum is known to play a significant role in the programming of obesity later in life [6,7], but little is known as to how the predominant HM carbohydrate lactose, its precursor glucose, and glucose uptake regulator insulin influence the development of BC during infancy.

Lactose is the least variable macronutrient in HM across the first 12 months of lactation [8,9], with estimated levels of approximately 67-78 g/L [5]. Lactose has been shown to upregulate gastrointestinal expression of the antimicrobial peptide cathelicidin in epithelial and monocytic cells, which may provide protection against pathogens and influence infant gut microbiota [10]. In addition, lactose can act as an energy source for Bifidobacterium spp. and Lactobacillus spp. [11], which are the dominant bacterial species found in the gut 
of the breastfed infant [12], indicating a potential effect on infant growth. There are limited studies investigating the effect of $\mathrm{HM}$ lactose on infant $\mathrm{BC}$, with the conflicting results. Two previous studies have shown that the concentration of HM lactose (4- 8 weeks lactation) was positively related to infant weight, BMI and adiposity gains between 3 and 12 months [13] and positively associated with an increasing weight-for-length z-score (WLZ) at 6-months among infants breastfed by mothers with overweight status and obesity [14]. However, another study reported that HM lactose concentration was not related to infant BC or anthropometrics during the first 12 months of lactation, yet higher calculated daily intakes (CDI) of lactose were associated with greater infant adiposity and decreased lean mass, suggesting that lactose could contribute to the development of BC in breastfed infants [6].

Insulin is produced by beta cells in the pancreas that facilitate glucose uptake and regulate carbohydrate, lipid and protein metabolism $[15,16]$. HM insulin concentrations change over the course of lactation, with lowest concentration reported in colostrum, followed by observed increases in mature milk [17]. However, its function with respect to infant growth and development of BC has not been firmly established. Existing studies describing the potential impact of $\mathrm{HM}$ insulin on infant health present conflicting results. One study reported no association between 1-month HM insulin concentration and infant body length, total fat mass (FM), \%FM, and trunk FM at 6 months [18]. A second study showed HM insulin concentration was negatively associated with infant weight, WLZ, BMI-for-age z-score (BMIAZ), and lean mass in infants from both mothers with normal weight and mothers with obesity at 1 month of age [19]. Yet a third study reported a U-shaped association between HM insulin concentration and infant z-scores [20]. The mixed evidence of $\mathrm{HM}$ insulin association with infant $\mathrm{BC}$ provides impetus for further investigations.

Glucose is a less abundant carbohydrate found in $\mathrm{HM}$ with an average concentration of $255.2 \pm 75.3 \mu \mathrm{g} / \mathrm{mL}$ over the first 6 months of lactation [21]. Glucose is a precursor for lactose [22] and its concentration in HM is proportional to the rate of milk secretion [23] and indicative of milk supply [24]. However, HM glucose concentration is also shown to be higher in mothers with obesity and overweight status compared to women of normal weight [25], and may therefore influence infant growth and health outcomes. A recent study showed that HM glucose concentration was positively associated with infant WLZ and BMIAZ, but not FM or lean mass of breastfed infants [19]; in contrast, two other studies found no association between concentration of HM glucose and infant BC [18,21]. Evidence regarding the influence of $\mathrm{HM}$ glucose on infant growth is scarce and requires further elucidation.

HM lactose, insulin and glucose may contribute to infant growth; however, the literature on the influence of $\mathrm{HM}$ components concentrations, and particularly intakes, on infant $\mathrm{BC}$ development is sparse. The aim of this cross-sectional study was to assess relationships of these HM components with measures of infant growth and $\mathrm{BC}$ in healthy term 3-month-old exclusively breastfed infants. In addition, relationships with maternal $\mathrm{BC}$ and 24-h milk intake were explored.

\section{Materials and Methods}

\subsection{Study Design}

Pregnant women were recruited from the community and existing online networks during the third trimester of pregnancy ( $>30$ weeks gestation) to participate in a birth cohort study. The BLOSOM cohort (Breastfeeding Longitudinal Observational Study of Mothers and kids) is a single-centre prospective cohort being conducted in Perth (Western Australia) designed to elucidate the mechanisms by which HM impacts infant growth, body composition and health. For the present study, the analysis was limited to dyads that provided milk samples and/or measured 24-h milk intakes and BC and anthropometrics measurements were available at 3 months postpartum $(n=67)$. Inclusion criteria were women self-reported as healthy with no major pregnancy complications, intention to exclusively breastfeed up to at least five months postpartum, and to breastfeed until 
12 months postpartum. Exclusion criteria included infant factors that could potentially influence growth and development of $\mathrm{BC}$, maternal smoking, pregnancy complications such as preterm labor and gestational diabetes mellitus (GDM). All mothers provided informed written consent to participate in the study, which was approved by the Human Research Ethics Committee at The University of Western Australia (RA/4/20/4023).

\subsection{Sample and Health Data Collection}

HM samples were collected by mothers at 2 months postpartum. Mothers elected one breast from which to donate the HM sample. Mothers were asked not to breastfeed or express milk from the elected breast for at least two hours prior to sample collection. Mothers washed their hands thoroughly with soap and water and wore disposable nitrile powder-free gloves (Complete Office Supplies, NSW, Australia) during sample collection. The nipple and areola of the expressing breast were cleaned with alcohol and chlorhexidine prep pads (70\% isopropyl alcohol and $2 \%$ chlorhexidine digluconate, Reynard Health Supplies, NSW, Australia), followed by rinsing with sterile saline solution (Livingstone, NSW, Australia) and drying with sterile gauze swabs (Livingstone, NSW, Australia). Up to $20 \mathrm{~mL}$ (otherwise as much as possible) of $\mathrm{HM}$ was hand-expressed directly into sterile tubes (Greiner Bio-One, Kremsmünster, Austria). HM samples were stored at $4{ }^{\circ} \mathrm{C}$ in the fridge at the home of the participant before being collected within 6-24 $\mathrm{h}$ and transported to the laboratory on ice, where they were immediately aliquoted into sterile tubes (Sarstedt, Numbrecht, Germany) and stored at $-80^{\circ} \mathrm{C}$ until further analysis.

Mothers answered a background questionnaire at the time of recruitment, and an infant and maternal questionnaire on sample collection day.

\subsection{Biochemical Analysis}

$\mathrm{HM}$ aliquots were thawed for $1 \mathrm{~h}$ at room temperature. Whole milk samples were used for measuring insulin and skim milk samples were used for measuring glucose and lactose concentrations. HM components were measured in duplicate. To acquire skim HM, samples were defatted by centrifugation in glass capillary tubes (Kimble Chase, Rockwood, $\mathrm{TN}, \mathrm{USA}$ ) at room temperature at $12,000 \times \mathrm{g}$ for $10 \mathrm{~min}$ [26]. The fat layer was removed by cutting the tubes below the bottom of the lipid layer and discarded.

Insulin concentrations in whole HM samples were analyzed using the Human Insulin ELISA kit (BioVendor, Brno, Czech Republic) according to the instructions of the manufacturer. A six-point standard curve ranging from $0-250 \mu \mathrm{IU} / \mathrm{mL}$ was constructed. The insulin detection limit was $0.26 \mu \mathrm{IU} / \mathrm{mL}$. The results obtained for controls were within the range specified by the manufacturer.

Glucose concentration in skim HM samples (diluted in 0.1 M K-Phosphate buffer, 1:2) was analyzed by enzymatic assay. Briefly, skimmed HM samples, standards and controls were pipetted $(5 \mu \mathrm{L})$ into wells on a 96-well microtiter plate and $200 \mu \mathrm{L}$ of the reagent cocktail ( $9.6 \mathrm{U} / \mathrm{mL}$ glucose oxidase, $2.5 \mathrm{U} / \mathrm{mL}$ peroxidase, reduced ABTS (2,2azino-di-(3-ethyl-benzthiazolinsulfonate)-6-sulfonate) and 0.1 M-phosphate buffer, $\mathrm{pH}$ 7.2) was added to each well. The plates were incubated for $5 \mathrm{~min}$ at room temperature in the dark. Absorbance was measured at $405 \mathrm{~nm}$ on a plate spectrophotometer (Enspire Multimode Plate Reader, Waltham, MA, USA). A seven-point standard curve ranging from $0-2 \mathrm{mmol} / \mathrm{L}$ was constructed. The glucose detection limit was $0.07 \mathrm{mmol} / \mathrm{L}$, and the inter-assay CV was $11.85 \%$. Recovery of a known amount of glucose added to the milk samples was $98 \% \pm 1.4 \%(\mathrm{n}=9)$. The results were converted into $\mathrm{g} / \mathrm{L}$ using the molecular weight of glucose $(180.16 \mathrm{~g} / \mathrm{mol})$.

Lactose concentration in skim HM samples (diluted in distilled de-ionized water, 1:150) was analyzed with the lactose colorimetric enzymatic assay according to the protocol as previously described by Mitoulas et al. [9]. A seven-point standard curve ranging from 0-300 $\mathrm{mmol} / \mathrm{L}$ was constructed. The detection limit was $0.51 \mathrm{mmol} / \mathrm{L}$, and the inter-assay $\mathrm{CV}$ was $4.23 \%$. Recovery of a known amount of lactose added to the milk samples was 
$101 \% \pm 3.14 \%(\mathrm{n}=8)$. The results were converted into $\mathrm{g} / \mathrm{L}$ using the molecular weight of lactose $(360.3 \mathrm{~g} / \mathrm{mol})$.

\subsection{Twenty-Four Hour Milk Intake}

Infant 24-h milk intake was measured at 3 months postpartum ( $3.3 \pm 0.4$ months; range: $2.2-4.2$ ) by mothers in their homes using the 24-h milk profile protocol as described previously [27]. Briefly, this involved mothers weighing their infant before and after each breastfeed on the electronic Baby Weigh Scales (Medela Inc., McHenry, IL, USA, resolution $2 \mathrm{~g}$, accuracy $\pm 0.034 \%$ ). HM intake (g) was calculated by subtracting the weight of the infant before the feed from the weight after the feed. 3-month 24-h milk intakes were considered representative of intakes during the exclusive breastfeeding period as there is no significant variation in HM intake from 1 to 6 months within infants [28].

\subsection{Calculated Daily Intakes of HM Components}

Calculated daily intakes (CDI) of HM components (g) were determined as the concentration of the component $(\mathrm{g} / \mathrm{L})$ multiplied by $24-\mathrm{h}$ intake that were converted from $\mathrm{g}$ to $\mathrm{mL}$ using the density of $\mathrm{HM}$ of $1.03 \mathrm{~g} / \mathrm{mL}$ [29].

\subsection{Anthropometry and Body Composition Measurements}

Anthropometric and BC measurements were performed for both mothers and infants at 3 months postpartum (3.1 \pm 0.1 months; range: $2.9-3.5)$. Maternal weight was measured using Seca electronic scales ( $\pm 0.1 \mathrm{~kg}$; Seca, Chino, CA, USA). Height was self-reported by mothers or measured against a marked wall. Infant clothes were removed before measuring weight using electronic scales (Medela Inc.). Infant crown to heel length was measured in supine position with an infantometer (Seca, Chino, CA, USA). Infant head circumference was measured with non-stretch tape to the nearest $0.1 \mathrm{~cm}$. Infant Z-scores (WLZ), weight-forage z-scores (WAZ), length-for-age z-scores (LAZ), BMIAZ and head circumference-for-age z-scores (HCAZ) were measured using the World Health Organization (WHO) Anthro software v3.2.2 [30].

Maternal and infant BC was measured with bioelectrical impedance spectroscopy using a battery-operated bioelectrical impedance analyser Impedimed SFB7 (ImpediMed, Brisbane, QLD, Australia) according to the protocols described previously by Gridneva et al. [31]. In addition to standard BC measurements (fat-free mass (FFM), FM, and \%FM), the heightnormalized BC indices of mothers and infants (FFMI, FMI) as well as FM to FFM ratio (FM/FFM) were calculated as described previously [6].

\subsection{Statistical Analysis}

Eleven groups of analyses were performed on these cross-sectional data using linear regression, all with a cofounder of infant birth weight.

Groups one to four had infant anthropometric and BC measures as response variables taken at 3 months postpartum (weight, length, BMI, head circumference, FFM, FFMI, FM, FMI, \%FM, FM/FFM and z-scores). Group one had explanatory variables of infant sex, gestational age, birth weight and 24-h milk intake; group two had explanatory variables based on milk concentrations of lactose, insulin and glucose; group three had explanatory variables based on $\mathrm{CDI}$ of lactose, insulin and glucose; group four were maternal factors (birth mode and BC measures; weight, BMI, FFM, FFMI, FM, \%FM, FMI, FM/FFM).

Groups five to seven had infant $24-\mathrm{h}$ milk intake as a response. Group five had explanatory variables of infant sex, gestational age and birth weight; group six had explanatory variables based on CDI of lactose, insulin and glucose; group seven had maternal explanatory variables.

Groups eight to ten had CDI of lactose, insulin and glucose as response variables. Group eight had a single explanatory variable of infant 24 -h milk intake; group nine was based on HM concentration of lactose, insulin and glucose; group ten were maternal factors. 
Group eleven response variables were based on concentrations of lactose, insulin and glucose; explanatory variables are maternal factors.

Descriptive statistics were reported as mean \pm standard deviation (SD) and range/ percentage; and modeling results as parameters estimates \pm standard error (SE). Missing data were dealt with using available case analysis. Statistical analyses were performed in R 4.0.2. The significance level for this investigative study was set at the $5 \%$ level. Due to the investigative nature of the study, p-values were not adjusted for multiple comparisons. The results should be interpreted in terms of the occurring patterns instead of focusing on the single significant test results.

\section{Results}

\subsection{Participants Characteristics}

Sixty-seven mother-infant pairs were recruited; ten were excluded due to formula use $(\mathrm{n}=2)$, absence of $B C$ and 24-h milk intake measurements $(\mathrm{n}=1)$, low birth weight $(\mathrm{n}=1)$, 24-h milk intake measured outside of the time point of study $(\mathrm{n}=2)$, or low 24-h milk intake $(<500 \mathrm{~mL} /$ day) $(\mathrm{n}=4)$. Missing data included maternal weight, BMI and BC measurements $(n=5)$, infant weight and length measurements, WLZ, WAZ, LAZ, BMI and BMIAZ ( $n=5)$, infant BC measurements $(n=7)$, infant head circumference and HCAZ $(n=10)$, and 24-h milk intake and CDI of lactose, insulin, and glucose $(n=12)$. The characteristics of the participants $(n=57)$ are shown in Table 1.

Table 1. Maternal and infant characteristics.

\begin{tabular}{lc}
\hline \multicolumn{1}{c}{ Characteristics } & Mean \pm SD (Min-Max) or n (\%) \\
\hline Maternal age at infant birth (years) & $32.7 \pm 4.6(25.1-46.4)$ \\
Maternal ethnicity & $48(84.2)$ \\
$\quad$ Caucasian & $5(8.8)$ \\
Asian & $4(70)$ \\
Other & $2.1 \pm 0.8(1-4)$ \\
Parity & \\
Mode of delivery & $36(63.2)$ \\
$\quad$ Vaginal & $14(24.6)$ \\
Elective caesarean section & $7(12.3)$ \\
Emergency caesarean section & $164.7 \pm 6.9(148.0-178.0)$ \\
Maternal height (cm) & $72.8 \pm 15.3(47.5-119.8)^{\mathrm{a}}$ \\
Maternal weight (kg) & $39.3 \pm 1.1(37.0-41.2)$ \\
Infant gestational age (weeks) & $27(47.4)$ \\
Infant sex & $30(52.6)$ \\
$\quad$ Male & \\
Female & $3.505 \pm 0.413(2.610-4.705)$ \\
Infant birth weight (kg) & $50.8 \pm 2.1(46.0-55.0)$ \\
Infant birth length (cm) & $6.150 \pm 0.756(4.638-8.410)^{\mathrm{a}}$ \\
Infant weight (kg) & $61.1 \pm 2.6(55.5-67.0)^{\mathrm{a}}$ \\
Infant length (cm) & $40.8 \pm 1.2(38.0-43.0)^{\mathrm{b}}$ \\
Infant head circumference (cm) & $792.8 \pm 176.1(511.7-1304.9)^{\mathrm{c}}$ \\
24-h milk intake (mL) &
\end{tabular}

Data are mean \pm SD and ranges or percentage. All anthropometrics were measured at 3 months postpartum unless otherwise stated. ${ }^{\mathrm{a}} n=52,{ }^{\mathrm{b}} n=47,{ }^{\mathrm{c}} n=45$.

\subsection{Human Milk Components}

HM components concentrations and CDI are presented in Table 2. 
Table 2. Human milk components presented as concentrations and 24-h intakes.

\begin{tabular}{ccc}
\hline Components & $\begin{array}{c}\text { Concentration } \\
\text { aean } \pm \text { SD (Min-Max) }\end{array}$ & $\begin{array}{c}\text { CDI }^{\mathbf{b}} \\
\text { Mean } \pm \text { SD (Min-Max) }\end{array}$ \\
\hline \multirow{2}{*}{ Lactose } & $86.56 \pm 7.91(\mathrm{~g} / \mathrm{L})$ & $68.35 \pm 16.63(\mathrm{~g} /$ day) \\
& $(69.91-106.09)$ & $(39.91-129.27)$ \\
Insulin & $1.48 \pm 1.14(\mathrm{ng} / \mathrm{mL})$ & $1.16 \pm 0.78(\mathrm{ng} /$ day $)$ \\
Glucose & $(0.46-5.90)$ & $(0.30-4.17)$ \\
& $0.26 \pm 0.09(\mathrm{~g} / \mathrm{L})$ & $0.20 \pm 0.09(\mathrm{~g} /$ day $)$ \\
& $(0.09-0.47)$ & $(0.05-0.49)$ \\
\hline
\end{tabular}

Data are mean \pm SD and ranges. ${ }^{\mathrm{a}} n=57,{ }^{\mathrm{b}} n=45, \mathrm{CDI}-$ calculated daily intakes based on 24-h milk intake.

\subsection{Maternal and Infant Body Composition}

Maternal and infant BC measurements and infant anthropometric z-scores at 3 months postpartum are presented in Table A1.

Mothers $(n=52)$ were classified as being either underweight (BMI $<18.5,3.9 \%, n=2$; $\% \mathrm{FM}<21,0 \%, n=0$ ), with normal weight (BMI 18.5-24.9, 40.4\%, $n=21$; \%FM 21-32.9, $32.7 \%, n=17$ ), with overweight status (BMI 25-29.9, 26.9\%, $n=14 ; \%$ FM 33-38.9, 34.6\%, $n=18$ ) or with obesity (BMI $>30,28.9 \%, n=15 ; \% \mathrm{FM}>39,32.7 \%, n=17$ ) [32].

Infant birth weight was positively associated with 3-month anthropometry, lean mass, adiposity, and z-score measurements. Additionally, infant gestational age was positively associated with LAZ (Table A2).

After accounting for infant birth weight, males were heavier, longer, with higher BMI and larger head circumference than females. Additionally, males had higher FFM, FFMI, and lower \%FM and FM/FFM ratio compared to female infants (Table A2).

Associations between maternal BC and infant anthropometrics, BC measures and $z$-scores are detailed in Table A3.

Higher maternal weight, BMI, FM, \%FM, FMI, FFM and FFMI, were associated with lower infant anthropometric measures (weight, BMI, and head circumference). Similarly, higher maternal age and $\mathrm{BC}$ measures were associated with lower infant lean body mass (FFM and FFMI), adiposity (FM, \%FM, FMI and FM/FFM) and $z$-scores (HCAZ, LAZ, WAZ, WLZ and BMIAZ) (Table A3).

\subsection{Twenty-Four Hour Milk Intake and HM Components}

Higher concentrations of all three HM components resulted in higher CDI (lactose: $0.817 \pm 0.284 \mathrm{~g} /$ day, $p=0.006$; insulin: $0.692 \pm 0.034 \mathrm{ng} /$ day, $p<0.001$; glucose: $0.880 \pm 0.080 \mathrm{~g} /$ day, $p<0.001)$; whilst higher 24-h milk intakes resulted in higher CDI of lactose $(0.085 \pm 0.006 \mathrm{~g} /$ day, $p<0.001)$ and glucose $(0.0003 \pm 0.0001 \mathrm{~g} /$ day, $p<0.001)$ but not insulin $(0.0004 \pm 0.0007 \mathrm{ng} /$ day, $p=0.53)$.

\subsection{Twenty-Four Hour Milk Intake, HM Components, and Infant Body Composition}

Significant associations between 24-h milk intake, CDI of HM components and infant $\mathrm{BC}$ are detailed in Table 3.

Higher CDI of lactose was associated with higher infant anthropometry (weight and length), adiposity (FM and FMI), lean body mass (FFM and FFMI) and WAZ (Table 3).

Concentrations and CDI of insulin and glucose were not associated with infant anthropometry and BC measurements (data not shown), except for CDI of glucose which was positively associated with infant head circumference.

Higher 24-h milk intake was associated with higher infant anthropometry (weight and length), lean body mass (FFM and FFMI), adiposity (FM and FMI) and WAZ (Table 3). 
Table 3. Associations between infant body composition and 24-h milk and lactose intakes at 3 months postpartum.

\begin{tabular}{|c|c|c|c|c|c|c|}
\hline \multirow{2}{*}{ Predictor } & \multirow{2}{*}{ Intercept } & \multirow{2}{*}{ SE } & \multirow{2}{*}{ Slope } & \multirow{2}{*}{ SE } & \multirow{2}{*}{$\begin{array}{c}\text { Predictor } \\
p \text {-Value }\end{array}$} & \multirow{2}{*}{$\begin{array}{c}\text { Infant Birth Weight } \\
p \text {-Value }\end{array}$} \\
\hline & & & & & & \\
\hline \multicolumn{7}{|c|}{ Infant weight (kg) } \\
\hline Lactose intake (g/day) & 1.779 & 0.643 & 0.017 & 0.005 & 0.001 & $<0.001$ \\
\hline 24-h milk intake (mL) & 1.672 & 0.638 & 0.002 & 0.0004 & $<0.001$ & $<0.001$ \\
\hline \multicolumn{7}{|c|}{ Infant length $(\mathrm{cm})$} \\
\hline Lactose intake (g/day) & 46.010 & 2.345 & 0.047 & 0.017 & 0.010 & $<0.001$ \\
\hline 24-h milk intake (mL) & 45.905 & 2.388 & 0.004 & 0.002 & 0.016 & $<0.001$ \\
\hline \multicolumn{7}{|c|}{ Head circumference $(\mathrm{cm})$} \\
\hline Glucose intake (g/day) & 35.338 & 1.495 & 4.304 & 1.885 & 0.028 & 0.004 \\
\hline \multicolumn{7}{|c|}{ Infant fat-free mass $(\mathrm{kg})$} \\
\hline Lactose intake (g/day) & 1.841 & 0.440 & 0.011 & 0.003 & 0.001 & $<0.001$ \\
\hline 24-h milk intake (mL) & 1.776 & 0.438 & 0.001 & 0.0003 & $<0.001$ & $<0.001$ \\
\hline \multicolumn{7}{|c|}{ Infant fat-free mass index $\left(\mathrm{kg} / \mathrm{m}^{2}\right)$} \\
\hline Lactose intake (g/day) & 9.757 & 1.257 & 0.026 & 0.009 & 0.009 & 0.011 \\
\hline 24-h milk intake (mL) & 9.591 & 1.252 & 0.003 & 0.001 & 0.005 & 0.013 \\
\hline \multicolumn{7}{|c|}{ Infant fat mass (kg) } \\
\hline Lactose intake (g/day) & -0.081 & 0.267 & 0.005 & 0.002 & 0.011 & $<0.001$ \\
\hline 24-h milk intake (mL) & -0.118 & 0.266 & 0.001 & 0.0002 & 0.006 & $<0.001$ \\
\hline \multicolumn{7}{|c|}{ Infant fat mass index $\left(\mathrm{kg} / \mathrm{m}^{2}\right)$} \\
\hline Lactose intake (g/day) & 0.956 & 0.815 & 0.014 & 0.006 & 0.028 & $<0.001$ \\
\hline 24-h milk intake (mL) & 0.855 & 0.813 & 0.001 & 0.001 & 0.017 & $<0.001$ \\
\hline \multicolumn{7}{|c|}{ Weight-for-age z-score } \\
\hline Lactose intake (g/day) & -5.200 & 0.792 & 0.017 & 0.006 & 0.007 & $<0.001$ \\
\hline 24-h milk intake (mL) & -5.330 & 0.785 & 0.002 & 0.001 & 0.003 & $<0.001$ \\
\hline
\end{tabular}

Data are parameter estimate \pm standard error of measurement (SE) after accounting for infant birth weight.

\subsection{Maternal Characteristics and Human Milk Components}

Associations between maternal characteristics and HM components and 24-h milk intake are detailed in Table 4.

Table 4. Associations between human milk components, 24-h milk intakes and maternal characteristics at 3 months postpartum.

\begin{tabular}{|c|c|c|c|c|c|c|}
\hline \multirow{2}{*}{ Maternal Predictor } & \multirow{2}{*}{ Intercept } & \multirow{2}{*}{ SE } & \multirow{2}{*}{ Slope } & \multirow{2}{*}{ SE } & \multirow{2}{*}{$\frac{\text { Predictor }}{p \text {-Value }}$} & \multirow{2}{*}{$\begin{array}{c}\text { Infant Birth Weight } \\
p \text {-Value }\end{array}$} \\
\hline & & & & & & \\
\hline \multicolumn{7}{|c|}{ Calculated daily intakes of HM components } \\
\hline \multicolumn{7}{|c|}{ Lactose (g/day) } \\
\hline Weight (kg) & 47.115 & 19.137 & -0.462 & 0.163 & 0.007 & 0.009 \\
\hline $\mathrm{BMI}\left(\mathrm{kg} / \mathrm{m}^{2}\right)$ & 55.258 & 19.195 & -1.501 & 0.459 & 0.002 & 0.007 \\
\hline FFM (kg) & 50.552 & 20.228 & -0.775 & 0.327 & 0.023 & 0.014 \\
\hline $\mathrm{FM}(\mathrm{kg})$ & 39.098 & 19.043 & -0.677 & 0.268 & 0.016 & 0.020 \\
\hline FFMI $\left(\mathrm{kg} / \mathrm{m}^{2}\right)$ & 63.565 & 20.691 & -3.000 & 0.987 & 0.004 & 0.007 \\
\hline FMI $\left(\mathrm{kg} / \mathrm{m}^{2}\right)$ & 42.531 & 19.061 & -1.909 & 0.721 & 0.011 & 0.024 \\
\hline
\end{tabular}


Table 4. Cont.

\begin{tabular}{|c|c|c|c|c|c|c|}
\hline \multirow{2}{*}{ Maternal Predictor } & \multirow{2}{*}{ Intercept } & \multirow{2}{*}{ SE } & \multirow{2}{*}{ Slope } & \multirow{2}{*}{ SE } & \multirow{2}{*}{$\begin{array}{c}\text { Predictor } \\
p \text {-Value }\end{array}$} & \multirow{2}{*}{$\frac{\text { Infant Birth Weight }}{p \text {-Value }}$} \\
\hline & & & & & & \\
\hline \multicolumn{7}{|c|}{ Concentrations of HM components } \\
\hline \multicolumn{7}{|c|}{ Insulin (ng/mL) } \\
\hline Age (years) & 2.392 & 1.666 & -0.073 & 0.032 & 0.027 & 0.24 \\
\hline $\mathrm{BMI}\left(\mathrm{kg} / \mathrm{m}^{2}\right)$ & -1.090 & 1.389 & 0.067 & 0.032 & 0.044 & 0.55 \\
\hline FMI $\left(\mathrm{kg} / \mathrm{m}^{2}\right)$ & -0.543 & 1.325 & 0.100 & 0.048 & 0.043 & 0.42 \\
\hline \multicolumn{7}{|c|}{ 24-h milk intake (mL) } \\
\hline Weight (kg) & 552.379 & 197.950 & -5.256 & 1.688 & 0.003 & 0.004 \\
\hline $\mathrm{BMI}\left(\mathrm{kg} / \mathrm{m}^{2}\right)$ & 630.592 & 201.169 & -16.005 & 4.811 & 0.002 & 0.005 \\
\hline FFM $(\mathrm{kg})$ & 590.075 & 210.553 & -8.743 & 3.403 & 0.014 & 0.008 \\
\hline FM (kg) & 461.557 & 197.438 & -7.740 & 2.781 & 0.008 & 0.011 \\
\hline FFMI $\left(\mathrm{kg} / \mathrm{m}^{2}\right)$ & 714.516 & 217.715 & -31.497 & 10.383 & 0.004 & 0.005 \\
\hline $\mathrm{FMI}\left(\mathrm{kg} / \mathrm{m}^{2}\right)$ & 495.925 & 199.567 & -20.608 & 7.548 & 0.009 & 0.016 \\
\hline
\end{tabular}

Data are parameter estimate \pm standard error of measurement (SE) after accounting for infant birth weight. BMI—body mass index; FFM—fat-free mass; FFMI—fat-free mass index; FM—fat mass; FMI—fat mass index; HM—human milk.

CDI of lactose and 24-h milk intake were negatively associated with maternal weight, BMI, lean body mass (FFM, and FFMI) and adiposity (FM and FMI). No significant association with maternal adiposity was seen for either CDI of insulin or glucose.

$\mathrm{HM}$ insulin concentration was positively associated with maternal BMI and adiposity (FMI) and negatively with age (Table 4).

\section{Discussion}

HM is a highly complex, biological fluid that has long-term beneficial health effects for infants $[3,4,33]$. This study sheds new light on the complex mechanisms by which HM components may influence infant BC. In this small investigative study, we found that at 3 months postpartum HM insulin and glucose concentrations and CDI were not associated with infant BC, whereas 24-h milk intake and CDI of HM lactose were positively associated with infant lean and fat mass as well as anthropometry. Furthermore, negative associations between maternal BC and infant 24-h milk intake and BC measurements were observed. Together these results emphasize the critical role HM components may play in programming infant growth and development in the early life (Figure 1).

In this cohort of healthy mothers and exclusively breastfed infants, we observed positive associations between CDI of lactose and infant anthropometry, lean body mass, adiposity and WAZ (Table 3; Figure 1). This emphasises the importance of measuring daily intakes, in addition to concentrations, of HM components. These results are similar to two previous studies that also analyzed associations between lactose intake and infant BC measures. In a smaller cohort Gridneva et al. reported higher CDI of lactose was associated with infant whole body adiposity (increased FM, FMI, \%FM, FM/FFM ratio, BMI and decreased 12-month FFMI) [6] as well as higher subcutaneous-abdominal fat areas [34], and Butte et al. reported that daily intake of lactose was positively correlated with infant weight and FFM gain but not with FM or \% FM, at 3 and 6 months [35]. Lactose is the major HM carbohydrate [36], providing a substantial proportion of energy to the infant, thus it is biologically plausible that the current and previous studies show the potential of HM lactose to promote weight gain and healthy fat deposition in the infant and thereby influence long-term health. 


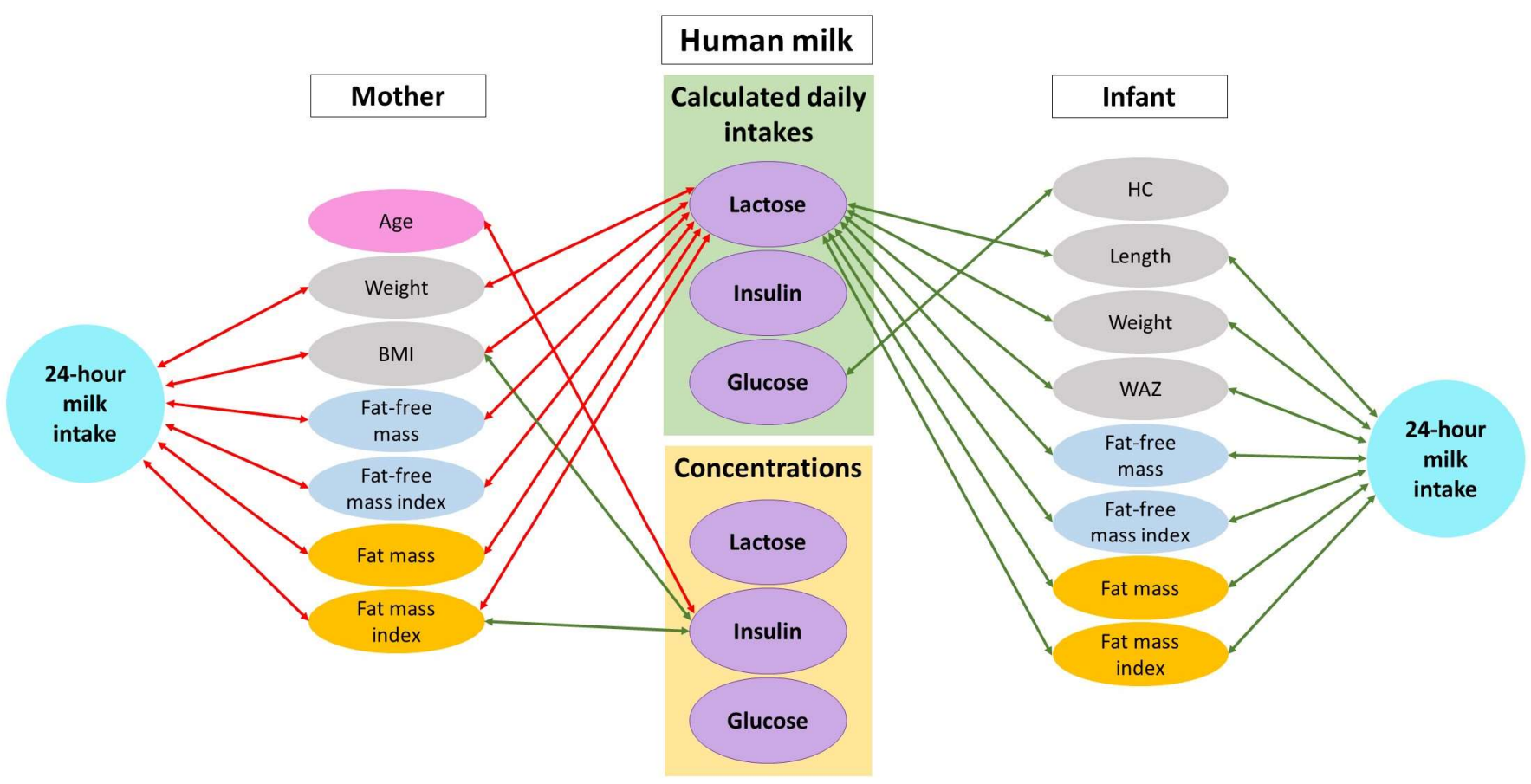

Figure 1. Possible lactocrine programming of the infant body composition as researched. Green arrows indicate positive associations and red arrows—negative associations. BMI—-body mass index; HC—-head circumference; WAZ—weight-forage z-score.

Contrary to intake, we observed no relationships between HM lactose concentration and infant anthropometry and BC measures. Our results are supported by four previous studies that reported no association between lactose concentration and infant anthropometry and $\mathrm{BC}$ measured during the first 12 months of lactation [6,34], and in the first 6 months in exclusively breastfed infants $[9,21]$. However, two other studies have reported significant results. One study showed that lactose concentration at 2-4 weeks lactation was positively associated with increased WLZ at 6 months, but only among infants of women with overweight status and obesity [14]. Another reported that HM \% lactose was positively related to infant weight, BMI and adiposity gains between three and 12 months [13]. Lactose concentration remains stable between 1 and 6 months of lactation [37], therefore, the lack of association between lactose concentration and infant adiposity may be explained by its role in maintaining osmotic pressure in HM [38]. Further work is required to better understand the roles of HM lactose in the breastfed infant.

We observed no relationships between HM insulin concentration and CDI and 3month infant anthropometry and BC measures, despite the presence of mothers with obesity $(n=15)$ and overweight status $(n=14)$. This is similar to two previous studies that showed no association between HM insulin 1- and 6-month concentrations and infant BC measures $[18,21]$. However, a third study reported negative associations with infant weight, WLZ, BMIAZ, and lean mass [19], and a fourth study reported a U-shaped association between $\mathrm{HM}$ insulin concentration and infant $\mathrm{BC}$, with intermediate concentrations predicting lower WLZ and BMI for age z-scores (BMIAZ) at 4 and 12 months [20]. The contrasting results are likely due to different study designs [20], and different methods used for assessing infant BC [19]. Alternatively, the lack of associations of HM insulin concentration and $\mathrm{CDI}$ with infant $\mathrm{BC}$ could be due to the central role of insulin in glucose metabolism [39] and as regulator of food intake and energy balance [40], or interactions with other hormones, such as leptin [41].

In our study HM glucose concentration and CDI were not related to infant lean body mass or adiposity. This is in contrast to a cross-sectional study [19], that reported that HM glucose concentrations were positively associated with 1-month infant WLZ and BMIAZ. Whereas a longitudinal study, ref. [21] reported no significant associations with infant 
$z$-scores. The differences between the studies could be due to differences in design and statistical methods. As glucose is a relatively small contributor to HM carbohydrate content [42] and acts as a universal and essential fuel in energy metabolism [22], it is possible that HM glucose may not directly modulate infant lean body mass and adiposity, but instead act as the principal stimulus for insulin secretion which in turn facilitates diffusion of glucose into fat and muscle cells [15], affecting infant growth. Interestingly, glucose CDI was positively associated with infant head circumference. Head circumference is regarded as a proxy measurement for infant brain size [43] and correlates with cognitive function and intracranial volume [44,45]. In 2- and 5-month old infants an increase in glucose metabolic activity in several brain regions was related to their functional maturation [46], which may also reflect on the head circumference. However, further work is required to confirm this finding of the present study.

HM intake and duration of exclusive breastfeeding are known to relate to infant growth rate [9,47-50]. We found positive associations between $24-\mathrm{h}$ milk intake and infant anthropometry (weight and length), lean body mass (FFM and FFMI), adiposity (FM and FMI) and $z$-scores (WAZ) (Table 3; Figure 1). Similarly, two previous studies have reported positive association between HM intake and infant growth during the first year of life. In the DARLING study, 3-month HM intake was positively associated with weight at 3 months [47]. However, the relationships between 24-h milk intake and infant BC were reported to be differential in the second study [31]; a positive association was found with adiposity and a negative association with lean mass. These data suggest that $24-\mathrm{h}$ milk intake influences BC development in addition to supporting the nutritional needs of the rapidly growing infant.

Our study also found strong positive associations between infant birth weight and anthropometry, lean body mass, adiposity, and z-score measurements, similar to previous studies that showed positive associations with FM and FMI [31,51]. Given that increased birth weight may predispose infants to obesity and type 2 diabetes mellitus later in life [52,53], it is important to understand the relationship between infant birth weight and $\mathrm{BC}$.

Our results showed that male infants, as expected, displayed higher anthropometry (weight, length, BMI and head circumference) and lean mass (FFM and FFMI) as well as lower adiposity (\%FM and FM/FFM; Table A2). This is in line with previous studies which showed greater FFM $[31,35,54,55]$ and lower \%FM [56] in male than in female infants. However, some studies have presented contrary results, suggesting no differences in \%FM between sexes [31,57]. The differences between the studies could be due to the use of different methods to assess BC such as air-displacement plethysmography [57], bioelectrical impedance spectroscopy [31], or small to modest sample size. The effect of infant sex on adiposity and HM composition during early life is still debated, BC developmental differences between infant sexes could be partially explained by sex-specific needs for early nutrition and differences in infants' hormones. However, limited human studies show contradictory results regarding differences in HM composition for infant sex [58-61], requiring further validation and clarification of sex-specific differences in HM composition and their impact on infant growth trajectories accounting for milk intake.

In this study, we also investigated associations between maternal characteristics/ adiposity and HM components. Higher maternal BMI and FMI were associated with higher HM insulin concentration (Table 4) and this is consistent with findings from previous studies $[17,20,25,62]$, with the exception of one [63]. It has been shown that mothers with overweight status and obesity have a higher concentration of HM insulin compared to mothers of normal weight $[25,64]$, suggesting maternal adiposity may play a role in regulation of HM insulin concentration. Whilst the underlying mechanisms involved are not yet fully elucidated, obesity is associated with increased insulin secretion independently of insulin resistance [65] and insulin is transported into $\mathrm{HM}$ at concentrations comparable to serum [66], suggesting either an active transport mechanism or a passive diffusion from serum. Furthermore, maternal age in this cohort was negatively associated with HM 
insulin (Table 4) which is in line with decreased insulin secretion observed with age, even after adjustments for adiposity and physical activity [67], again supporting active/passive transport.

A novel finding of this study is that maternal BC was not associated with either glucose concentration, or CDI (data not shown). In contrast, one previous study showed that mothers with overweight and obesity status had higher HM glucose concentrations compared to mothers of normal weight, and that higher concentrations were inter-correlated with pre-pregnancy BMI [25]. Research in this area is, however, extremely limited and further work is needed to validate the present findings and to discern the mechanisms by which maternal BC may affect HM glucose.

We found no significant association between maternal adiposity and HM lactose concentration, similar to previous studies from Western populations [6,68-70]. However, two studies in Asian populations reported a negative association between HM lactose concentration and maternal BMI [71,72]. The differences between studies may be due to differences in maternal BMI as participants in Asian studies had a lower BMI range compared to those in the Western studies, the use of different statistical methods, or due to genetic/dietary differences between populations. Contrary to lactose concentration, CDI of lactose, as well as 24-h milk intake, were negatively related to maternal weight, BMI, and $\mathrm{BC}$ measures suggesting the intakes are driven either via the maternal HM production and/or infant demand. Similarly, a recent study showed a negative relationship between maternal FM and HM intake [73], supporting the notion that maternal characteristics may influence the volume of HM consumed by the infant. To date, only one study has analyzed the relationship between maternal BC and CDI of lactose [6], reporting no associations, however, this study was based on a small sample size $(n=20)$.

The current study is one of few to investigate relationships between maternal BC and infant $\mathrm{BC}$ measurements during exclusive breastfeeding. Previous studies, based on maternal BMI [74-77], anthropometry [78] and BC measured with bioelectrical impedance analysis during pregnancy [79], reported positive associations with infant birth weight, FM, and \%FM. Our study showed no associations between maternal BC measures and infant $\% \mathrm{FM}$, however maternal $\mathrm{BMI}$ and $\mathrm{BC}$ measures were negatively associated with infant anthropometry (weight, head circumference and BMI), adiposity (FM and FMI), lean mass (FFM, FFMI), and $z$-scores (WAZ, WLZ, BMIAZ and HCAZ) (Table A3). In line with our results, a small longitudinal study reported that increased maternal adiposity was related to lower infant FFM over the course of the first year of lactation [31], and a cross-sectional study showed that increased maternal BMI was associated with lower infant FFM in infants under one month of age [76]. This suggests that early life BC changes may be influenced by maternal $\mathrm{BC}$ status. Therefore, maintaining healthy maternal adiposity pre-pregnancy and during lactation may be beneficial for the development of infant lean and FM [31].

This small investigative study has focused on exclusively breastfed infants; thus, it is reflective of the influence of $\mathrm{HM}$ components on the development of infant $\mathrm{BC}$. The strengths of this study include assessment of maternal and infant BC as well as 24-h milk intake and CDI of HM components. However, it should be noted that the study includes some limitations, such as the cross-sectional nature of the study, the moderate sample size and no access to the gold standard BC method or ability to account for maternal dietary intake. Our population consisted of term, healthy, exclusively breastfed infants from predominantly Caucasian mothers of higher social-economic status; therefore, the results may not be transferable to other populations.

\section{Conclusions}

The findings from this investigative study demonstrate that increased CDI of lactose and 24-h milk intake relate to increased infant growth and BC measures during the first 3 months of life, whilst concentrations and CDI of HM insulin and glucose do not relate to infant BC development. Additionally, maternal lean mass and adiposity influence infant 24-h milk intake as well as infant BC development. These findings highlight the importance 
of daily intakes, not just concentrations, of HM components and have implications for infant $\mathrm{BC}$ development and potentially health later in life.

Author Contributions: Conceptualization, A.S.C., L.F.S., C.T.L., M.S.P., D.T.G. and Z.G.; Methodology, A.S.C., L.F.S., C.T.L., M.S.P., K.M. and D.T.G.; Data curation, A.S.C. and Z.G.; Formal analysis, A.S.C., Z.G., K.M. and A.R.; Investigation, A.S.C., L.F.S., C.T.L., M.S.P. and D.T.G.; Visualization, A.S.C., Z.G. and A.R.; Writing—original draft, A.S.C., A.R. and Z.G.; Writing-review \& editing, Z.G., L.F.S., A.R., C.T.L., M.S.P., K.M. and D.T.G.; Funding acquisition, D.T.G.; Resources, D.T.G. and M.S.P.; Supervision, L.F.S., C.T.L., M.S.P. and D.T.G. All authors have read and agreed to the published version of the manuscript.

Funding: This research was supported by an unrestricted research grant from Medela AG (Switzerland), administered by The University of Western Australia. A.S.C. was supported by an additional SIRF (Scholarships for International Research Fees) scholarship from The University of Western Australia. M.S.P. is supported by the Women and Infants Research Foundation, and a National Health and Medical Research Council project grant (APP \#1144040).

Institutional Review Board Statement: This study was conducted in accordance with the guidelines of the Declaration of Helsinki and approved by the Human Research Ethics Committee at The University of Western Australia (RA/4/20/4023).

Informed Consent Statement: Informed consent was obtained from all participants involved in the study.

Data Availability Statement: The data presented in this study are available from the corresponding author upon reasonable request.

Acknowledgments: We are grateful to the families who participated in the study and sincerely thank Erika van den Dries for assisting in data and sample collection and Ashleigh Warden for assisting in body composition analyses.

Conflicts of Interest: A.S.C., Z.G., L.F.S., C.T.L., and D.T.G. are supported by an unrestricted research grant from Medela AG, administered by The University of Western Australia. The funding bodies had no role in the design of the study, collection/analysis/interpretation of data, writing of the manuscript, or in the decision to publish the results. Other authors have no conflicts of interest to disclose.

\section{Appendix A}

Table A1. Maternal and infant body composition at 3 months postpartum.

\begin{tabular}{ccccc}
\hline Body Composition & $\begin{array}{c}\text { Infant } \\
\text { (Male) } \\
\text { Mean } \pm \text { SD } \\
\text { (Min-Max) }\end{array}$ & $\begin{array}{c}\text { Infant } \\
\text { (Female) } \mathbf{d} \\
\text { Mean } \pm \text { SD } \\
\text { (Min-Max) }\end{array}$ & $\begin{array}{c}\text { Infant } \\
\text { (Pooled) } \\
\text { Mean } \pm \text { SD } \\
\text { (Min-Max) }\end{array}$ & $\begin{array}{c}\text { Mother } \\
\text { Mean } \pm \text { SD } \\
\text { (Min-Max) }\end{array}$ \\
Fat-free mass $(\mathrm{kg})$ & $4.92 \pm 0.46$ & $4.27 \pm 0.27$ & $4.57 \pm 0.49$ & $45.68 \pm 8.46$ \\
& $(3.80-6.01) \mathrm{a}$ & $(3.83-4.76)$ & $(3.80-6.01) \mathrm{e}$ & $(18.00-70.89)$ \\
Fat-free mass index $\left(\mathrm{kg} / \mathrm{m}^{2}\right)$ & $17.78 \pm 1.03$ & $14.19 \pm 0.67$ & $14.92 \pm 1.17$ & $16.85 \pm 2.79$ \\
& $(13.70-17.93) \mathrm{a}$ & $(12.93-15.41)$ & $(12.93-17.93) \mathrm{e}$ & $(6.30-23.96)$ \\
Fat mass $(\mathrm{kg})$ & $1.65 \pm 0.35$ & $1.51 \pm 0.24$ & $1.58 \pm 0.30$ & $26.75 \pm 9.42$ \\
& $(0.84-2.50) \mathrm{a}$ & $(1.06-1.94)$ & $(0.84-2.50) \mathrm{e}$ & $(11.25-53.93)$ \\
Fat mass index $\left(\mathrm{kg} / \mathrm{m}^{2}\right)$ & $5.28 \pm 0.98$ & $5.01 \pm 0.70$ & $5.14 \pm 0.84$ & $9.88 \pm 3.41$ \\
& $(3.02-7.47) \mathrm{a}$ & $(3.80-6.22)$ & $(3.02-7.47) \mathrm{e}$ & $(3.94-18.99)$ \\
Fat mass $(\%)$ & $24.88 \pm 2.49$ & $25.99 \pm 1.96$ & $25.48 \pm 2.27$ & $35.91 \pm 6.16$ \\
& $(18.05-29.76) \mathrm{a}$ & $(21.52-29.04)$ & $(18.05-29.76) \mathrm{e}$ & $(21.88-53.35)$ \\
Fat mass to fat-free $\mathrm{mass}$ ratio & $0.33 \pm 0.04$ & $0.35 \pm 0.04$ & $0.34 \pm 0.04$ & $0.58 \pm 0.16$ \\
Body mass index $\left(\mathrm{kg} / \mathrm{m}^{2}\right)$ & $(0.22-0.42) \mathrm{a}$ & $(0.27-0.41)$ & $(0.22-0.42) \mathrm{e}$ & $(0.37-1.14)$ \\
& $16.97 \pm 1.32$ & $15.98 \pm 1.08$ & $16.46 \pm 1.29$ & $26.88 \pm 5.21$ \\
& $(15.06-19.92) \mathrm{b}$ & $(14.05-17.99)$ & $(14.05-19.92) \mathrm{f}$ & $(18.00-40.95)$ \\
\hline
\end{tabular}


Table A1. Cont.

\begin{tabular}{|c|c|c|c|c|}
\hline Body Composition & $\begin{array}{c}\text { Infant } \\
\text { (Male) } \\
\text { Mean } \pm \text { SD } \\
\text { (Min-Max) }\end{array}$ & $\begin{array}{c}\text { Infant } \\
\text { (Female) }^{d} \\
\text { Mean } \pm \text { SD } \\
(\text { Min-Max) }\end{array}$ & $\begin{array}{c}\text { Infant } \\
\text { (Pooled) } \\
\text { Mean } \pm \text { SD } \\
\text { (Min-Max) }\end{array}$ & $\begin{array}{c}\text { Mother } \mathrm{f} \\
\text { Mean } \pm \text { SD } \\
(\text { Min-Max) }\end{array}$ \\
\hline \multicolumn{5}{|c|}{ Infant z-scores } \\
\hline Weight-for-length z-score & $\begin{array}{c}0.04 \pm 0.92 \\
(-1.23-2.54) b\end{array}$ & $\begin{array}{l}-0.22 \pm 0.83 \\
(-1.82-1.11)\end{array}$ & $\begin{array}{l}-0.09 \pm 0.89 \\
(-1.82-2.54) \mathrm{f}\end{array}$ & \\
\hline Weight-for-age z-score & $\begin{array}{c}0.19 \pm 1.03 \\
(-2.79-2.49) b\end{array}$ & $\begin{array}{c}-0.15 \pm 0.71 \\
(-1.64 .-1.15)\end{array}$ & $\begin{array}{c}0.01 \pm 0.89 \\
(-2.79-2.49) \mathrm{f}\end{array}$ & \\
\hline Length-for-age z-score & $\begin{array}{c}0.32 \pm 1.31 \\
(-3.09-2.83) b\end{array}$ & $\begin{array}{c}0.11 \pm 1.11 \\
(-2.25-2.18)\end{array}$ & $\begin{array}{c}0.21 \pm 1.20 \\
(-3.09-2.83) \mathrm{f}\end{array}$ & \\
\hline BMI-for-age z-score & $\begin{array}{c}0.10 \pm 0.90 \\
(-1.39-1.95) b\end{array}$ & $\begin{array}{l}-0.28 \pm 0.72 \\
(-1.63-1.05)\end{array}$ & $\begin{array}{l}-0.10 \pm 0.82 \\
(-1.63-1.95) \mathrm{f}\end{array}$ & \\
\hline Head circumference-for-age z-score & $\begin{array}{c}0.55 \pm 0.93 \\
(-1.34-2.08) c\end{array}$ & $\begin{array}{c}0.67 \pm 0.90 \\
(-1.07-2.56) b\end{array}$ & $\begin{array}{c}0.62 \pm 0.91 \\
(-1.34-2.56) \mathrm{g}\end{array}$ & \\
\hline
\end{tabular}

Data are mean \pm SD and ranges. ${ }^{\mathrm{a}} n=23,{ }^{\mathrm{b}} n=25,{ }^{\mathrm{c}} n=22,{ }^{\mathrm{d}} n=27,{ }^{\mathrm{e}} n=50,{ }^{\mathrm{f}} n=52,{ }^{\mathrm{g}} n=47$. BMI-body mass index.

Table A2. Associations between infant characteristics and body composition at 3 months postpartum.

\begin{tabular}{|c|c|c|c|c|c|c|}
\hline \multirow{2}{*}{ Infant Predictor } & \multirow{2}{*}{ Intercept } & \multirow{2}{*}{ SE } & \multirow{2}{*}{ Slope } & \multirow{2}{*}{ SE } & \multirow{2}{*}{$\frac{\text { Predictor }}{p \text {-Value }}$} & \multirow{2}{*}{$\begin{array}{c}\text { Infant Birth Weight } \\
p \text {-Value }\end{array}$} \\
\hline & & & & & & \\
\hline \multicolumn{7}{|c|}{ Infant weight $(\mathrm{kg})$} \\
\hline Sex (male) & 2.259 & 0.561 & 0.638 & 0.137 & $<0.001$ & $<0.001$ \\
\hline Birth weight (kg) & 2.143 & 0.666 & 0.001 & 0.0002 & $<0.001$ & NA \\
\hline \multicolumn{7}{|c|}{ Infant length $(\mathrm{cm})$} \\
\hline Sex (male) & 47.669 & 2.208 & 1.459 & 0.540 & 0.010 & $<0.001$ \\
\hline Birth weight (kg) & 47.405 & 2.340 & 0.004 & 0.001 & $<0.001$ & NA \\
\hline \multicolumn{7}{|c|}{ Infant body mass index $\left(\mathrm{kg} / \mathrm{m}^{2}\right)$} \\
\hline Sex (male) & 13.434 & 1.343 & 0.892 & 0.329 & 0.009 & 0.060 \\
\hline Birth weight (kg) & 13.272 & 1.425 & 0.001 & 0.0004 & 0.029 & NA \\
\hline \multicolumn{7}{|c|}{ Infant head circumference $(\mathrm{cm})$} \\
\hline Sex (male) & 36.160 & 1.350 & 0.684 & 0.298 & 0.027 & 0.003 \\
\hline Birth weight (kg) & 36.176 & 1.413 & 0.001 & 0.0004 & 0.002 & NA \\
\hline \multicolumn{7}{|c|}{ Infant fat-free mass $(\mathrm{kg})$} \\
\hline Sex (male) & 2.271 & 0.323 & 0.559 & 0.080 & $<0.001$ & $<0.001$ \\
\hline Birth weight (kg) & 2.104 & 0.454 & 0.001 & 0.0001 & $<0.001$ & NA \\
\hline \multicolumn{7}{|c|}{ Infant fat-free mass index $\left(\mathrm{kg} / \mathrm{m}^{2}\right)$} \\
\hline Sex (male) & 10.763 & 0.863 & 1.433 & 0.215 & $<0.001$ & $<0.001$ \\
\hline Birth weight (kg) & 10.332 & 1.188 & 0.001 & 0.0003 & $<0.001$ & NA \\
\hline \multicolumn{7}{|c|}{ Infant fat mass $(\mathrm{kg})$} \\
\hline Birth weight (kg) & -0.062 & 0.264 & 0.001 & 0.0001 & $<0.001$ & NA \\
\hline \multicolumn{7}{|c|}{ Infant fat mass index $\left(\mathrm{kg} / \mathrm{m}^{2}\right)$} \\
\hline Birth weight (kg) & 0.967 & 0.779 & 0.001 & 0.0002 & $<0.001$ & NA \\
\hline \multicolumn{7}{|c|}{ Infant fat mass $(\%)$} \\
\hline Sex (male) & 15.374 & 2.073 & -1.616 & 0.516 & 0.003 & $<0.001$ \\
\hline Birth weight (kg) & 15.860 & 2.249 & 0.003 & 0.001 & $<0.001$ & NA \\
\hline
\end{tabular}


Table A2. Cont.

\begin{tabular}{|c|c|c|c|c|c|c|}
\hline \multirow{2}{*}{ Infant Predictor } & \multirow{2}{*}{ Intercept } & \multirow{2}{*}{ SE } & \multirow{2}{*}{ Slope } & \multirow{2}{*}{ SE } & \multirow{2}{*}{$\begin{array}{c}\text { Predictor } \\
p \text {-Value }\end{array}$} & \multirow{2}{*}{$\begin{array}{c}\text { Infant Birth Weight } \\
p \text {-Value }\end{array}$} \\
\hline & & & & & & \\
\hline \multicolumn{7}{|c|}{ Infant fat mass to fat-free mass ratio } \\
\hline Sex (male) & 0.159 & 0.037 & -0.028 & 0.009 & 0.004 & $<0.001$ \\
\hline Birth weight (kg) & 0.167 & 0.040 & 0.0001 & 0.000 & $<0.001$ & NA \\
\hline \multicolumn{7}{|c|}{ Weight-for-age z-score } \\
\hline Birth weight (kg) & -4.877 & 0.758 & 0.001 & 0.0002 & $<0.001$ & NA \\
\hline \multicolumn{7}{|c|}{ Length-for-age z-score } \\
\hline GA (weeks) & -15.416 & 4.565 & 0.275 & 0.129 & 0.038 & $<0.001$ \\
\hline Birth weight (kg) & -5.956 & 1.081 & 0.002 & 0.0003 & $<0.001$ & NA \\
\hline \multicolumn{7}{|c|}{ BMI-for-age z-score } \\
\hline Birth weight (kg) & -2.213 & 0.907 & 0.001 & 0.0003 & 0.023 & NA \\
\hline \multicolumn{7}{|c|}{ Head circumference-for-age z-score } \\
\hline Birth weight (kg) & -2.786 & 1.107 & 0.001 & 0.0003 & 0.003 & NA \\
\hline
\end{tabular}

Data are parameter estimate \pm standard error of measurement (SE) after accounting for infant birth weight. BMI—body mass index; GA—gestational age.

Table A3. Associations between infant and maternal body composition at 3 months postpartum.

\begin{tabular}{|c|c|c|c|c|c|c|}
\hline \multirow{2}{*}{ Maternal Predictor } & \multirow{2}{*}{ Intercept } & \multirow{2}{*}{ SE } & \multirow{2}{*}{ Slope } & \multirow{2}{*}{ SE } & \multirow{2}{*}{$\begin{array}{c}\text { Predictor } \\
p \text {-Value }\end{array}$} & \multirow{2}{*}{$\begin{array}{c}\text { Infant Birth Weight } \\
p \text {-Value }\end{array}$} \\
\hline & & & & & & \\
\hline \multicolumn{7}{|c|}{ Infant weight $(\mathrm{kg})$} \\
\hline Weight (kg) & 2.489 & 0.655 & -0.013 & 0.006 & 0.025 & $<0.001$ \\
\hline $\operatorname{BMI}\left(\mathrm{kg} / \mathrm{m}^{2}\right)$ & 2.836 & 0.646 & -0.049 & 0.015 & 0.002 & $<0.001$ \\
\hline FM (kg) & 2.273 & 0.634 & -0.022 & 0.009 & 0.014 & $<0.001$ \\
\hline FM (\%) & 3.034 & 0.748 & -0.029 & 0.013 & 0.026 & $<0.001$ \\
\hline FFMI $\left(\mathrm{kg} / \mathrm{m}^{2}\right)$ & 2.938 & 0.679 & -0.083 & 0.029 & 0.006 & $<0.001$ \\
\hline FMI $\left(\mathrm{kg} / \mathrm{m}^{2}\right)$ & 2.408 & 0.628 & -0.066 & 0.023 & 0.006 & $<0.001$ \\
\hline \multicolumn{7}{|c|}{ Infant body mass index $\left(\mathrm{kg} / \mathrm{m}^{2}\right)$} \\
\hline Weight (kg) & 14.308 & 1.327 & -0.038 & 0.011 & 0.001 & $<0.001$ \\
\hline $\mathrm{BMI}\left(\mathrm{kg} / \mathrm{m}^{2}\right)$ & 14.808 & 1.372 & -0.108 & 0.032 & 0.001 & 0.001 \\
\hline FFM (kg) & 14.535 & 1.366 & -0.066 & 0.020 & 0.002 & 0.001 \\
\hline $\mathrm{FM}(\mathrm{kg})$ & 13.621 & 1.304 & -0.058 & 0.018 & 0.002 & 0.002 \\
\hline FM (\%) & 15.468 & 1.573 & -0.072 & 0.027 & 0.010 & 0.011 \\
\hline FFMI $\left(\mathrm{kg} / \mathrm{m}^{2}\right)$ & 15.160 & 1.423 & -0.198 & 0.060 & 0.002 & 0.001 \\
\hline FMI $\left(\mathrm{kg} / \mathrm{m}^{2}\right)$ & 13.876 & 1.328 & -0.150 & 0.048 & 0.003 & 0.004 \\
\hline \multicolumn{7}{|c|}{ Infant head circumference $(\mathrm{cm})$} \\
\hline FFM (kg) & 37.037 & 1.396 & -0.044 & 0.019 & 0.023 & $<0.001$ \\
\hline FFMI $\left(\mathrm{kg} / \mathrm{m}^{2}\right)$ & 37.791 & 1.431 & -0.152 & 0.054 & 0.007 & $<0.001$ \\
\hline \multicolumn{7}{|c|}{ Infant fat-free mass $(\mathrm{kg})$} \\
\hline $\mathrm{BMI}\left(\mathrm{kg} / \mathrm{m}^{2}\right)$ & 2.549 & 0.456 & -0.029 & 0.011 & 0.009 & $<0.001$ \\
\hline FM $(\mathrm{kg})$ & 2.197 & 0.438 & -0.013 & 0.006 & 0.032 & $<0.001$ \\
\hline FM (\%) & 2.743 & 0.521 & -0.020 & 0.009 & 0.030 & $<0.001$ \\
\hline FFMI $\left(\mathrm{kg} / \mathrm{m}^{2}\right)$ & 2.646 & 0.510 & -0.051 & 0.024 & 0.042 & $<0.001$ \\
\hline FMI $\left(\mathrm{kg} / \mathrm{m}^{2}\right)$ & 2.293 & 0.435 & -0.042 & 0.016 & 0.012 & $<0.001$ \\
\hline FM/FFM & 2.456 & 0.468 & -0.715 & 0.337 & 0.039 & $<0.001$ \\
\hline
\end{tabular}


Table A3. Cont.

\begin{tabular}{|c|c|c|c|c|c|c|}
\hline \multirow{2}{*}{ Maternal Predictor } & \multirow{2}{*}{ Intercept } & \multirow{2}{*}{ SE } & \multirow{2}{*}{ Slope } & \multirow{2}{*}{ SE } & \multirow{2}{*}{$\begin{array}{c}\text { Predictor } \\
p \text {-Value }\end{array}$} & \multirow{2}{*}{$\begin{array}{c}\text { Infant Birth Weight } \\
p \text {-Value }\end{array}$} \\
\hline & & & & & & \\
\hline \multicolumn{7}{|c|}{ Infant fat-free mass index $\left(\mathrm{kg} / \mathrm{m}^{2}\right)$} \\
\hline Weight (kg) & 11.053 & 1.161 & -0.025 & 0.010 & 0.015 & $<0.001$ \\
\hline BMI $\left(\mathrm{kg} / \mathrm{m}^{2}\right)$ & 11.613 & 1.174 & -0.084 & 0.028 & 0.004 & $<0.001$ \\
\hline FM (kg) & 10.634 & 1.116 & -0.043 & 0.015 & 0.007 & $<0.001$ \\
\hline $\mathrm{FM}(\%)$ & 12.242 & 1.343 & -0.061 & 0.024 & 0.013 & $<0.001$ \\
\hline FFMI $\left(\mathrm{kg} / \mathrm{m}^{2}\right)$ & 11.849 & 1.327 & -0.141 & 0.063 & 0.030 & $<0.001$ \\
\hline FMI $\left(\mathrm{kg} / \mathrm{m}^{2}\right)$ & 10.885 & 1.118 & -0.122 & 0.041 & 0.005 & $<0.001$ \\
\hline FM/FFM & 11.372 & 1.210 & -2.113 & 0.871 & 0.019 & $<0.001$ \\
\hline \multicolumn{7}{|c|}{ Infant fat mass $(\mathrm{kg})$} \\
\hline Weight (kg) & 0.073 & 0.263 & -0.005 & 0.002 & 0.041 & $<0.001$ \\
\hline $\operatorname{BMI}\left(\mathrm{kg} / \mathrm{m}^{2}\right)$ & 0.194 & 0.265 & -0.017 & 0.006 & 0.010 & $<0.001$ \\
\hline FFMI $\left(\mathrm{kg} / \mathrm{m}^{2}\right)$ & 0.337 & 0.288 & -0.037 & 0.014 & 0.009 & $<0.001$ \\
\hline FMI $\left(\mathrm{kg} / \mathrm{m}^{2}\right)$ & 0.030 & 0.258 & -0.020 & 0.010 & 0.038 & $<0.001$ \\
\hline \multicolumn{7}{|c|}{ Infant fat mass index $\left(\mathrm{kg} / \mathrm{m}^{2}\right)$} \\
\hline Weight (kg) & 1.409 & 0.768 & -0.015 & 0.007 & 0.023 & $<0.001$ \\
\hline $\operatorname{BMI}\left(\mathrm{kg} / \mathrm{m}^{2}\right)$ & 1.720 & 0.785 & -0.049 & 0.018 & 0.010 & $<0.001$ \\
\hline FFM (kg) & 1.564 & 0.810 & -0.027 & 0.013 & 0.047 & $<0.001$ \\
\hline $\mathrm{FM}(\mathrm{kg})$ & 1.119 & 0.757 & -0.022 & 0.010 & 0.042 & $<0.001$ \\
\hline FFMI $\left(\mathrm{kg} / \mathrm{m}^{2}\right)$ & 2.148 & 0.851 & -0.110 & 0.041 & 0.009 & $<0.001$ \\
\hline FMI $\left(\mathrm{kg} / \mathrm{m}^{2}\right)$ & 1.235 & 0.763 & -0.059 & 0.028 & 0.041 & $<0.001$ \\
\hline \multicolumn{7}{|c|}{ Infant fat mass (\%) } \\
\hline Age (years) & 19.908 & 2.888 & -0.119 & 0.056 & 0.039 & $<0.001$ \\
\hline \multicolumn{7}{|c|}{ Infant fat mass to fat-free mass ratio } \\
\hline Age (years) & 0.236 & 0.052 & -0.002 & 0.001 & 0.0495 & $<0.001$ \\
\hline \multicolumn{7}{|c|}{ Weight-for-length z-score } \\
\hline Weight (kg) & 0.083 & 0.961 & -0.028 & 0.008 & 0.001 & 0.069 \\
\hline $\operatorname{BMI}\left(\mathrm{kg} / \mathrm{m}^{2}\right)$ & 0.310 & 1.020 & -0.069 & 0.024 & 0.005 & 0.15 \\
\hline FFM (kg) & 0.264 & 0.985 & -0.049 & 0.015 & 0.002 & 0.070 \\
\hline $\mathrm{FM}(\mathrm{kg})$ & -0.431 & 0.953 & -0.041 & 0.013 & 0.002 & 0.15 \\
\hline FM $(\%)$ & 0.738 & 1.159 & -0.046 & 0.020 & 0.023 & 0.40 \\
\hline FFMI $\left(\mathrm{kg} / \mathrm{m}^{2}\right)$ & 0.524 & 1.059 & -0.126 & 0.045 & 0.007 & 0.15 \\
\hline FMI $\left(\mathrm{kg} / \mathrm{m}^{2}\right)$ & -0.285 & 0.983 & -0.098 & 0.036 & 0.008 & 0.25 \\
\hline \multicolumn{7}{|c|}{ Weight-for-age z-score } \\
\hline Weight (kg) & -4.451 & 0.739 & -0.016 & 0.006 & 0.015 & $<0.001$ \\
\hline $\operatorname{BMI}\left(\mathrm{kg} / \mathrm{m}^{2}\right)$ & -4.128 & 0.743 & -0.053 & 0.017 & 0.004 & $<0.001$ \\
\hline FM $(\mathrm{kg})$ & -4.728 & 0.721 & -0.025 & 0.010 & 0.014 & $<0.001$ \\
\hline FM (\%) & -3.969 & 0.861 & -0.030 & 0.015 & 0.048 & $<0.001$ \\
\hline FFMI $\left(\mathrm{kg} / \mathrm{m}^{2}\right)$ & -4.044 & 0.783 & -0.087 & 0.033 & 0.011 & $<0.001$ \\
\hline FMI $\left(\mathrm{kg} / \mathrm{m}^{2}\right)$ & -4.594 & 0.722 & -0.070 & 0.026 & 0.010 & $<0.001$ \\
\hline \multicolumn{7}{|c|}{ Length-for-age z-score } \\
\hline Age (year) & -3.828 & 1.382 & -0.063 & 0.027 & 0.024 & $<0.001$ \\
\hline
\end{tabular}


Table A3. Cont.

\begin{tabular}{|c|c|c|c|c|c|c|}
\hline \multirow{2}{*}{ Maternal Predictor } & \multirow{2}{*}{ Intercept } & \multirow{2}{*}{ SE } & \multirow{2}{*}{ Slope } & \multirow{2}{*}{ SE } & \multirow{2}{*}{$\begin{array}{c}\text { Predictor } \\
p \text {-Value }\end{array}$} & \multirow{2}{*}{$\begin{array}{c}\text { Infant Birth Weight } \\
p \text {-Value }\end{array}$} \\
\hline & & & & & & \\
\hline \multicolumn{7}{|c|}{ BMI-for-age z-score } \\
\hline Weight (kg) & -1.744 & 0.894 & -0.017 & 0.008 & 0.025 & 0.003 \\
\hline $\operatorname{BMI}\left(\mathrm{kg} / \mathrm{m}^{2}\right)$ & -1.518 & 0.923 & -0.049 & 0.021 & 0.027 & 0.004 \\
\hline FFM (kg) & -1.588 & 0.905 & -0.033 & 0.014 & 0.020 & 0.003 \\
\hline $\mathrm{FM}(\mathrm{kg})$ & -2.058 & 0.877 & -0.026 & 0.012 & 0.032 & 0.005 \\
\hline FM (\%) & -1.134 & 1.031 & -0.035 & 0.018 & 0.0495 & 0.012 \\
\hline FFMI $\left(\mathrm{kg} / \mathrm{m}^{2}\right)$ & -1.284 & 0.946 & -0.098 & 0.040 & 0.019 & 0.003 \\
\hline FMI $\left(\mathrm{kg} / \mathrm{m}^{2}\right)$ & -1.942 & 0.887 & -0.068 & 0.032 & 0.041 & 0.007 \\
\hline \multicolumn{7}{|c|}{ Head circumference-for-age z-score } \\
\hline FFM $(\mathrm{kg})$ & -2.112 & 1.093 & -0.034 & 0.015 & 0.023 & $<0.001$ \\
\hline FFMI $\left(\mathrm{kg} / \mathrm{m}^{2}\right)$ & -1.733 & 1.152 & -0.099 & 0.043 & 0.026 & $<0.001$ \\
\hline
\end{tabular}

Data are parameter estimate \pm standard error of measurement (SE) after accounting for infant birth weight. BMI-body mass index; FFM—fat-free mass; FFMI—fat-free mass index; FM—fat mass; FMI—fat mass index; FM/FFM—fat mass to fat-free mass ratio.

\section{References}

1. Pacheco, A.R.; Barile, D.; Underwood, M.A.; Mills, D.A. The impact of the milk glycobiome on the neonate gut microbiota. Annu. Rev. Anim. Biosci. 2015, 3, 419-445. [CrossRef] [PubMed]

2. Geddes, D.T.; Gridneva, Z.; Perrella, S.L.; Mitoulas, L.R.; Kent, J.C.; Stinson, L.F.; Lai, C.T.; Sakalidis, V.; Twigger, A.-J.; Hartmann, P.E. 25 years of research in human lactation: From discovery to translation. Nutrients 2021, 13, 3071. [CrossRef] [PubMed]

3. Savarino, G.; Corsello, A.; Corsello, G. Macronutrient balance and micronutrient amounts through growth and development. Ital. J. Pediatrics 2021, 47, 109. [CrossRef] [PubMed]

4. Andreas, N.J.; Kampmann, B.; Mehring Le-Doare, K. Human breast milk: A review on its composition and bioactivity. Early Hum. Dev. 2015, 91, 629-635. [CrossRef] [PubMed]

5. Ballard, O.; Morrow, A.L. Human milk composition: Nutrients and bioactive factors. Pediatric Clin. 2013, 60, 49-74. [CrossRef]

6. Gridneva, Z.; Rea, A.; Tie, W.J.; Lai, C.T.; Kugananthan, S.; Ward, L.C.; Murray, K.; Hartmann, P.E.; Geddes, D.T. Carbohydrates in human milk and body composition of term infants during the first 12 months of lactation. Nutrients 2019, 11, 1472. [CrossRef] [PubMed]

7. Wells, J.C.; Chomtho, S.; Fewtrell, M.S. Programming of body composition by early growth and nutrition. Proc. Nutr. Soc. 2007, 66, 423-434. [CrossRef] [PubMed]

8. Nommsen, L.A.; Lovelady, C.A.; Heinig, M.J.; Lonnerdal, B.; Dewey, K.G. Determinants of energy, protein, lipid, and lactose concentrations in human milk during the first 12 mo of lactation: The DARLING study. Am. J. Clin. Nutr. 1991, 53, 457-465. [CrossRef]

9. Mitoulas, L.R.; Kent, J.C.; Cox, D.B.; Owens, R.A.; Sherriff, J.L.; Hartmann, P.E. Variation in fat, lactose and protein in human milk over 24h and throughout the first year of lactation. Br. J. Nutr. 2007, 88, 29-37. [CrossRef]

10. Cederlund, A.; Kai-Larsen, Y.; Printz, G.; Yoshio, H.; Alvelius, G.; Lagercrantz, H.; Stromberg, R.; Jornvall, H.; Gudmundsson, G.H.; Agerberth, B. Lactose in human breast milk an inducer of innate immunity with implications for a role in intestinal homeostasis. PLoS ONE 2013, 8, e53876. [CrossRef]

11. Forsgard, R.A. Lactose digestion in humans: Intestinal lactase appears to be constitutive whereas the colonic microbiome is adaptable. Am. J. Clin. Nutr. 2019, 110, 273-279. [CrossRef]

12. Wall, R.; Ross, R.P.; Ryan, C.A.; Hussey, S.; Murphy, B.; Fitzgerald, G.F.; Stanton, C. Role of gut microbiota in early infant development. Clin. Med. Pediatrics 2009, 3, 45-54. [CrossRef] [PubMed]

13. Prentice, P.; Ong, K.K.; Schoemaker, M.H.; van Tol, E.A.; Vervoort, J.; Hughes, I.A.; Acerini, C.L.; Dunger, D.B. Breast milk nutrient content and infancy growth. Acta Paediatr. 2016, 105, 641-647. [CrossRef] [PubMed]

14. Young, B.E.; Patinkin, Z.W.; Pyle, L.; de la Houssaye, B.; Davidson, B.S.; Geraghty, S.; Morrow, A.L.; Krebs, N. Markers of oxidative stress in human milk do not differ by maternal BMI but are related to infant growth trajectories. Matern. Child Health J. 2017, 21, 1367-1376. [CrossRef]

15. Wilcox, G. Insulin and insulin resistance. Clin. Biochem. Rev. 2005, 26, 19-39. [PubMed]

16. Sonksen, P.; Sonksen, J. Insulin: Understanding its action in health and disease. Br. J. Anaesth. 2000, 85, 69-79. [CrossRef] [PubMed]

17. Yu, X.; Rong, S.S.; Sun, X.; Ding, G.; Wan, W.; Zou, L.; Wu, S.; Li, M.; Wang, D. Associations of breast milk adiponectin, leptin, insulin and ghrelin with maternal characteristics and early infant growth: A longitudinal study. Br. J. Nutr. 2018, 120, 1380-1387. [CrossRef] 
18. Fields, D.A.; George, B.; Williams, M.; Whitaker, K.; Allison, D.B.; Teague, A.; Demerath, E.W. Associations between human breast milk hormones and adipocytokines and infant growth and body composition in the first 6 months of life. Pediatric Obes. 2017, 12 (Suppl. 1), 78-85. [CrossRef]

19. Fields, D.A.; Demerath, E.W. Relationship of insulin, glucose, leptin, IL-6 and TNF-alpha in human breast milk with infant growth and body composition. Pediatric Obes. 2012, 7, 304-312. [CrossRef]

20. Chan, D.; Goruk, S.; Becker, A.B.; Subbarao, P.; Mandhane, P.J.; Turvey, S.E.; Lefebvre, D.; Sears, M.R.; Field, C.J.; Azad, M.B. Adiponectin, leptin and insulin in breast milk: Associations with maternal characteristics and infant body composition in the first year of life. Int. J. Obes. 2018, 42, 36-43. [CrossRef]

21. Goran, M.I.; Martin, A.A.; Alderete, T.L.; Fujiwara, H.; Fields, D.A. Fructose in breast milk is positively associated with infant body composition at 6 months of age. Nutrients 2017, 9, 146. [CrossRef] [PubMed]

22. Zhao, F.Q. Biology of glucose transport in the mammary gland. J. Mammary Gland. Biol. Neoplasia 2014, 19, 3-17. [CrossRef] [PubMed]

23. Neville, M.C.; Hay, W.W.; Fennessey, P. Physiological significance of the concentration of human milk glucose. Protoplasma 1990, 159, 118-128. [CrossRef]

24. Nagel, E.M.; Kummer, L.; Jacobs, D.R., Jr.; Foster, L.; Duncan, K.; Johnson, K.; Harnack, L.; Haapala, J.; Kharoud, H.; Gallagher, T.; et al. Human milk glucose, leptin, and insulin predict cessation of full breastfeeding and initiation of formula use. Breastfeed. Med. 2021. ahead of print. [CrossRef] [PubMed]

25. Ahuja, S.; Boylan, M.; Hart, S.L.; Román-Shriver, C.; Spallholz, J.E.; Pence, B.C.; Sawyer, B.G. Glucose and insulin levels are increased in obese and overweight mothers' breast-milk. Food Nutr. Sci. 2011, 2, 201-206. [CrossRef]

26. Tie, W.J.; Kent, J.C.; Tat Lai, C.; Rea, A.; Hepworth, A.R.; Murray, K.; Geddes, D.T. Reproducibility of the creamatocrit technique for the measurement of fat content in human milk. Food Chem. 2021, 356, 129708. [CrossRef]

27. Kent, J.C.; Mitoulas, L.R.; Cregan, M.D.; Ramsay, D.T.; Doherty, D.A.; Hartmann, P.E. Volume and frequency of breastfeedings and fat content of breast milk throughout the day. Pediatrics 2006, 117, e387-e395. [CrossRef]

28. Kent, J.C.; Hepworth, A.R.; Sherriff, J.L.; Cox, D.B.; Mitoulas, L.R.; Hartmann, P.E. Longitudinal changes in breastfeeding patterns from 1 to 6 months of lactation. Breastfeed. Med. 2013, 8, 401-407. [CrossRef]

29. Neville, M.C.; Keller, R.; Seacat, J.; Lutes, V.; Neifert, M.; Casey, C.; Allen, J.; Archer, P. Studies in human lactation: Milk volumes in lactating women during the onset of lactation and full lactation. Am. J. Clin. Nutr. 1988, 48, 1375-1386. [CrossRef] [PubMed]

30. Organization WHO. Child Growth Standards Software. WHO Anthro Survey Analyser and Other Tools (version 3.2.2). Available online: https:/ / www.who.int/childgrowth/software/en/ (accessed on 16 June 2021).

31. Gridneva, Z.; Rea, A.; Hepworth, A.R.; Ward, L.C.; Lai, C.T.; Hartmann, P.E.; Geddes, D.T. Relationships between breastfeeding patterns and maternal and infant body composition over the first 12 months of lactation. Nutrients 2018, 10, 45. [CrossRef] [PubMed]

32. Gallagher, D.; Heymsfield, S.B.; Heo, M.; Jebb, S.A.; Murgatroyd, P.R.; Sakamoto, Y. Healthy percentage body fat ranges: An approach for developing guidelines based on body mass index. Am. J. Clin. Nutr. 2000, 72, 694-701. [CrossRef] [PubMed]

33. Kelishadi, R.; Farajian, S. The protective effects of breastfeeding on chronic non-communicable diseases in adulthood: A review of evidence. Adv. Biomed. Res. 2014, 3, 3. [CrossRef] [PubMed]

34. Gridneva, Z.; Rea, A.; Lai, C.T.; Tie, W.J.; Kugananthan, S.; Murray, K.; Hartmann, P.E.; Geddes, D.T. Development of visceral and subcutaneous-abdominal adipose tissue in breastfed infants during first year of lactation. Nutrients 2021, 13, 3294. [CrossRef] [PubMed]

35. Butte, N.F.; Hopkinson, J.M.; Wong, W.W.; Smith, E.O.; Ellis, K.J. Body composition during the first 2 years of life: An updated reference. Pediatric Res. 2000, 47, 578-585. [CrossRef] [PubMed]

36. Leghi, G.E.; Netting, M.J.; Middleton, P.F.; Wlodek, M.E.; Geddes, D.T.; Muhlhausler, A.B.S. The impact of maternal obesity on human milk macronutrient composition: A systematic review and meta-analysis. Nutrients 2020, 12, 934. [CrossRef]

37. Grote, V.; Verduci, E.; Scaglioni, S.; Vecchi, F.; Contarini, G.; Giovannini, M.; Koletzko, B.; Agostoni, C. Breast milk composition and infant nutrient intakes during the first 12 months of life. Eur. J. Clin. Nutr. 2016, 70, 250-256. [CrossRef]

38. Martin, C.R.; Ling, P.R.; Blackburn, G.L. Review of infant feeding: Key features of breast milk and infant formula. Nutrients 2016, 8, 279. [CrossRef]

39. Fields, D.A.; Schneider, C.R.; Pavela, G. A narrative review of the associations between six bioactive components in breast milk and infant adiposity. Obesity 2016, 24, 1213-1221. [CrossRef] [PubMed]

40. Guyenet, S.J.; Schwartz, M.W. Clinical review: Regulation of food intake, energy balance, and body fat mass: Implications for the pathogenesis and treatment of obesity. J. Clin. Endocrinol. Metab. 2012, 97, 745-755. [CrossRef] [PubMed]

41. Kieffer, T.J.; Habener, J.F. The adipoinsular axis: Effects of leptin on pancreatic beta-cells. Am. J. Physiol. -Endocrinol. Metab. 2000, 278, E1-E14. [CrossRef]

42. Emmett, P.M.; Rogers, I.S. Properties of human milk and their relationship with maternal nutrition. Early Hum. Dev. 1997, 49, S7-S28. [CrossRef]

43. Henrichs, J.; Schenk, J.J.; Roza, S.J.; van den Berg, M.P.; Schmidt, H.G.; Steegers, E.A.; Hofman, A.; Jaddoe, V.W.; Verhulst, F.C.; Tiemeier, H. Maternal psychological distress and fetal growth trajectories: The Generation R Study. Psychol. Med. 2010, 40, 633-643. [CrossRef] [PubMed] 
44. Bray, P.F.; Shields, W.D.; Wolcott, G.J.; Madsen, J.A. Occipitofrontal head circumference-An accurate measure of intracranial volume. J. Pediatrics 1969, 75, 303-305. [CrossRef]

45. Rollins, J.D.; Collins, J.S.; Holden, K.R. United States head circumference growth reference charts: Birth to 21 years. J. Pediatrics 2010, 156, 907-913.e2. [CrossRef] [PubMed]

46. Kinnala, A.; Suhonen-Polvi, H.; Aarimaa, T.; Kero, P.; Korvenranta, H.; Ruotsalainen, U.; Bergman, J.; Haaparanta, M.; Solin, O.; Nuutila, P.; et al. Cerebral metabolic rate for glucose during the first six months of life: An FDG positron emission tomography study. Arch. Dis. Child.-Fetal Neonatal Ed. 1996, 74, F153-F157. [CrossRef] [PubMed]

47. Dewey, K.G.; Heinig, M.J.; Nommsen, L.A.; Lonnerdal, B. Maternal versus infant factors related to breast milk intake and residual milk volume: The DARLING study. Pediatrics 1991, 87, 829-837. [PubMed]

48. Kent, J.C.; Mitoulas, L.; Cox, D.B.; Owens, R.A.; Hartmann, P.E. Breast volume and milk production during extended lactation in women. Exp. Physiol. 1999, 84, 435-447. [CrossRef] [PubMed]

49. Giugliani, E.R.J. Growth in exclusively breastfed infants. J. Pediatr. 2019, 95 (Suppl. 1), 79-84. [CrossRef] [PubMed]

50. Jayasinghe, S.; Herath, M.P.; Beckett, J.M.; Ahuja, K.D.K.; Byrne, N.M.; Hills, A.P. Exclusivity of breastfeeding and body composition: Learnings from the baby-bod study. Int. Breastfeed. J. 2021, 16, 41. [CrossRef] [PubMed]

51. Chomtho, S.; Wells, J.C.; Davies, P.S.; Lucas, A.; Fewtrell, M.S. Early growth and body composition in infancy. Adv. Exp. Med. Biol. 2009, 646, 165-168. [CrossRef] [PubMed]

52. Dabelea, D.; Pettitt, D.J.; Hanson, R.L.; Imperatore, G.; Bennett, P.H.; Knowler, W.C. Birth weight, type 2 diabetes, and insulin resistance in Pima Indian children and young adults. Diabetes Care 1999, 22, 944-950. [CrossRef] [PubMed]

53. Rich-Edwards, J.W.; Colditz, G.A.; Stampfer, M.J.; Willett, W.C.; Gillman, M.W.; Hennekens, C.H.; Speizer, F.E.; Manson, J.E. Birthweight and the risk for type 2 diabetes mellitus in adult women. Ann. Intern. Med. 1999, 130, 278-284. [CrossRef] [PubMed]

54. Carberry, A.E.; Colditz, P.B.; Lingwood, B.E. Body composition from birth to 4.5 months in infants born to non-obese women. Pediatric Res. 2010, 68, 84-88. [CrossRef] [PubMed]

55. Eriksson, B.; Lof, M.; Forsum, E. Body composition in full-term healthy infants measured with air displacement plethysmography at 1 and 12 weeks of age. Acta Paediatr. 2010, 99, 563-568. [CrossRef] [PubMed]

56. Gridneva, Z.; Hepworth, A.R.; Ward, L.C.; Lai, C.T.; Hartmann, P.E.; Geddes, D.T. Determinants of body composition in breastfed infants using bioimpedance spectroscopy and ultrasound skinfolds-methods comparison. Pediatric Res. 2017, 81, 423-433. [CrossRef] [PubMed]

57. Roggero, P.; Gianni, M.L.; Orsi, A.; Piemontese, P.; Amato, O.; Liotto, N.; Morlacchi, L.; Taroni, F.; Fields, D.A.; Catalano, P.M.; et al. Quality of growth in exclusively breast-fed infants in the first six months of life: An Italian study. Pediatric Res. 2010, 68, 542-544. [CrossRef] [PubMed]

58. Powe, C.E.; Knott, C.D.; Conklin-Brittain, N. Infant sex predicts breast milk energy content. Am. J. Hum. Biol. 2010, 22, 50-54. [CrossRef] [PubMed]

59. Fujita, M.; Roth, E.; Lo, Y.J.; Hurst, C.; Vollner, J.; Kendell, A. In poor families, mothers' milk is richer for daughters than sons: A test of Trivers-Willard hypothesis in agropastoral settlements in Northern Kenya. Am. J. Phys. Anthropol. 2012, 149, 52-59. [CrossRef] [PubMed]

60. Hahn, W.H.; Song, J.H.; Song, S.; Kang, N.M. Do gender and birth height of infant affect calorie of human milk? An association study between human milk macronutrient and various birth factors. J. Matern.-Fetal Neonatal Med. 2017, 30, 1608-1612. [CrossRef] [PubMed]

61. Quinn, E.A. No evidence for sex biases in milk macronutrients, energy, or breastfeeding frequency in a sample of Filipino mothers. Am. J. Phys. Anthropol. 2013, 152, 209-216. [CrossRef] [PubMed]

62. Ley, S.H.; Hanley, A.J.; Sermer, M.; Zinman, B.; O'Connor, D.L. Associations of prenatal metabolic abnormalities with insulin and adiponectin concentrations in human milk. Am. J. Clin. Nutr. 2012, 95, 867-874. [CrossRef]

63. Shehadeh, N.; Khaesh-Goldberg, E.; Shamir, R.; Perlman, R.; Sujov, P.; Tamir, A.; Makhoul, I.R. Insulin in human milk: Postpartum changes and effect of gestational age. Arch. Dis. Child.-Fetal Neonatal Ed. 2003, 88, F214-F216. [CrossRef]

64. Young, B.E.; Patinkin, Z.; Palmer, C.; de la Houssaye, B.; Barbour, L.A.; Hernandez, T.; Friedman, J.E.; Krebs, N.F. Human milk insulin is related to maternal plasma insulin and BMI: But other components of human milk do not differ by BMI. Eur. J. Clin. Nutr. 2017, 71, 1094-1100. [CrossRef]

65. Van Vliet, S.; Koh, H.E.; Patterson, B.W.; Yoshino, M.; LaForest, R.; Gropler, R.J.; Klein, S.; Mittendorfer, B. Obesity is associated with increased basal and postprandial beta-cell insulin secretion even in the absence of insulin resistance. Diabetes 2020, 69, 2112-2119. [CrossRef] [PubMed]

66. Whitmore, T.J.; Trengove, N.J.; Graham, D.F.; Hartmann, P.E. Analysis of insulin in human breast milk in mothers with type 1 and type 2 diabetes mellitus. Int. J. Endocrinol. 2012, 2012, 296368. [CrossRef] [PubMed]

67. Muller, D.C.; Elahi, D.; Tobin, J.D.; Andres, R. The effect of age on insulin resistance and secretion: A review. Semin. Nephrol. 1996, 16, 289-298. [PubMed]

68. Kugananthan, S.; Gridneva, Z.; Lai, C.T.; Hepworth, A.R.; Mark, P.J.; Kakulas, F.; Geddes, D.T. Associations between maternal body composition and appetite hormones and macronutrients in human milk. Nutrients 2017, 9, 252. [CrossRef]

69. Barbosa, L.; Butte, N.F.; Villalpando, S.; Wong, W.W.; Smith, E.O. Maternal energy balance and lactation performance of Mesoamerindians as a function of body mass index. Am. J. Clin. Nutr. 1997, 66, 575-583. [CrossRef] 
70. Bzikowska-Jura, A.; Czerwonogrodzka-Senczyna, A.; Oledzka, G.; Szostak-Wegierek, D.; Weker, H.; Wesolowska, A. Maternal nutrition and body composition during breastfeeding: Association with human milk composition. Nutrients 2018, 10, 1379. [CrossRef]

71. Chang, N.; Jung, J.A.; Kim, H.; Jo, A.; Kang, S.; Lee, S.W.; Yi, H.; Kim, J.; Yim, J.G.; Jung, B.M. Macronutrient composition of human milk from Korean mothers of full term infants born at 37-42 gestational weeks. Nutr. Res. Pract. 2015, 9, 433-438. [CrossRef]

72. Yang, T.; Zhang, Y.; Ning, Y.; You, L.; Ma, D.; Zheng, Y.; Yang, X.; Li, W.; Wang, J.; Wang, P. Breast milk macronutrient composition and the associated factors in urban Chinese mothers. Chin. Med. J. 2014, 127, 1721-1725. [PubMed]

73. Diana, A.; Haszard, J.J.; Houghton, L.A.; Gibson, R.S. Breastmilk intake among exclusively breastfed Indonesian infants is negatively associated with maternal fat mass. Eur. J. Clin. Nutr. 2019, 73, 1206-1208. [CrossRef]

74. Carlsen, E.M.; Renault, K.M.; Norgaard, K.; Nilas, L.; Jensen, J.E.; Hyldstrup, L.; Michaelsen, K.F.; Cortes, D.; Pryds, O. Newborn regional body composition is influenced by maternal obesity, gestational weight gain and the birthweight standard score. Acta Paediatr. 2014, 103, 939-945. [CrossRef] [PubMed]

75. Tikellis, G.; Ponsonby, A.L.; Wells, J.C.; Pezic, A.; Cochrane, J.; Dwyer, T. Maternal and infant factors associated with neonatal adiposity: Results from the Tasmanian Infant Health Survey (TIHS). Int. J. Obes. 2012, 36, 496-504. [CrossRef] [PubMed]

76. Hull, H.R.; Dinger, M.K.; Knehans, A.W.; Thompson, D.M.; Fields, D.A. Impact of maternal body mass index on neonate birthweight and body composition. Am. J. Obstet. Gynecol. 2008, 198, 416.e1-416.e6. [CrossRef] [PubMed]

77. Sewell, M.F.; Huston-Presley, L.; Super, D.M.; Catalano, P. Increased neonatal fat mass, not lean body mass, is associated with maternal obesity. Am. J. Obstet. Gynecol. 2006, 195, 1100-1103. [CrossRef] [PubMed]

78. Nahar, S.; Mascie-Taylor, C.G.; Begum, H.A. Maternal anthropometry as a predictor of birth weight. Public Health Nutr. 2007, 10, 965-970. [CrossRef] [PubMed]

79. Farah, N.; Stuart, B.; Donnelly, V.; Kennelly, M.M.; Turner, M.J. The influence of maternal body composition on birth weight. Eur. J. Obstet. Gynecol. Reprod. Biol. 2011, 157, 14-17. [CrossRef] 